\title{
Employee Engagement Millennial Generation (Gen Y) Reviewed from Leadership Factors, Internal Communication, and Organization Climate
}

\author{
Bebi Aulia P.A ${ }^{1}$, Parwoto ${ }^{2}$, Ahmad Badawi Saluy ${ }^{2}$ \\ \{55118310030@student.mercubuana.ac.id ${ }^{1}$, parwoto.parwoto@mercubuana.ac.id², \\ ahmad.badawi@mercubuana.ac.id $\left.{ }^{3}\right\}$ \\ Mercu Buana University, Indonesia ${ }^{123}$
}

\begin{abstract}
This research is to examine the factors of employee engagement of millennial generation (GEN Y) to the company in terms of leadership, internal communication and organizational climate. This study uses a quantitative approach to test the proposed hypothesis. The subjects of this study were all employees in the millennial age group at PT. MNC Networks with a total sample of 90 people. The study uses a data collection method with a Likert scale that provides five answer choices. Processing and analyzing research data using PLS (Partial Least Square) software version 3.0. The results of this study indicate that $14 \%$ o leadership factors have an influence on the organizational climate, with a tcount of 2.866 and a P value of 0.005 . Leadership apparently also has a direct influence on employee engagement in the amount of $22.90 \%$, with a tcount of 4.866 and a $\mathrm{P}$ value of 0.000 , while for internal communication factors also affect the organizational climate of $16.30 \%$, with a tcount of 3.069 and a $\mathrm{P}$ value of 0.002 , but for internal communication does not have a direct influence on employee engagement where the significance test results only show $0.10 \%$, with a tcount of 0.370 and a $\mathrm{P}$ value of 0.712 . Factors of organizational climate turned out to have an influence on employee engagement that is equal to $10.90 \%$, with a tcount of 2.739 and a $\mathrm{P}$ value of 0.007 . The structural model formed for organizational climate $=0.385 *$ leadership $+0.415 *$ internal communication, while the structural model for employee engagement $=0.522 *$ leadership- $0.041 *$ internal communication $+0.328 *$ organizational climate.
\end{abstract}

Keywords: Employee Engagement, Leadership, Internal Communication, Organizational Climate

\section{Introduction}

Current economic developments, where economic competitiveness is not only local (domestic) market but also global (international), the impact of the industrial revolution 4.0, which emphasizes the digital economy, artificial intelligence, big data, robots, and so on [1], [2] makes the company must be able to manage its employees to continue to produce productive performance so that the company can continue to survive and continue to benefit. The effect of this economic development was also felt and faced by one of the National Private Radio Group Companies in Jakarta, which is based on conventional radio, where the company must remain able to survive in the face of the onslaught of digital radio media. 
Employees as company assets are expected to be able to provide productive results on the performance carried out. Employees within the company currently consist of a mix of three generations, where they are equally required to carry out their work functions optimally and productively, so as to be able to encourage the company to achieve its stated goals. According to Kupperschmidt [3] generation is a group of people who have the same birth year, age, location and also historical experience or events in the same individual, who have a significant influence in their growth phase. So, it can be said that a generation is a group of individuals who experience the same events in the same time period.

The existing generation of employees in the company are the baby boomers, $\mathrm{X}$ generation, and millennial generation (generation Y). According to Putra [4], the Baby Boomers generation is the generation whose birth years span between 1946-1964, Generation X is the generation born between the years between 1965-1980, while the Millennial generation is generation born between 1981-1999. The existence of this generation difference, making a gap between employees, because of differences in work style, as well as in the perspective of seeing a job and problems.

The existing phenomenon, employees who fall into the category of millennial generation tend to be seen as having no attachment to the work they are undertaking. To produce these products, employees must have a sense of attachment to the company and its work [5]. While Macey, W.H., Schneider, B., Barbera, K.M., \& Young, S [6] explained that there are three main factors that drive employee engagement, namely 1) Organizational factors; 2) Management and leadership factors; 3) Work condition factors. Employees who are able to produce good, productive and positive performance are employees who have a sense of engagement. According to Sapna Popli, Irfan A. Rizvi [7] work engagement refers to the relationship between employees and their work, while employee engagement is related to the relationship between employees and the organization.

The results of observations in the field of PT. MNC Networks obtained several indications that reflect the absence of employee engagement with the company in millennial generation. One of the factors that shows the lack of employee engagement with the company, seen from the high turnover rate of millennial employees, this shows the problem of employee attachment to millennial employees, because individuals with high levels of engagement tend to stay longer and lack the desire to resign (voluntary turnover) [8].

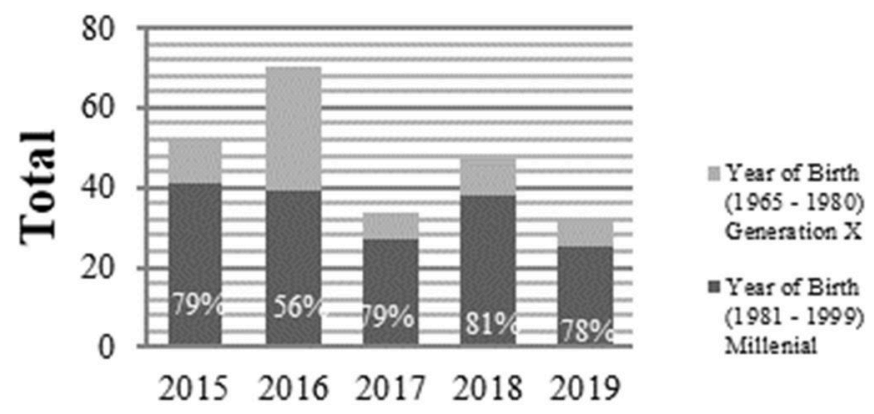

Year of resigned

Fig 1. Comparison of \% Turnover between Millennials and Generation X, period 2015-2019 
From the table above it can be seen that there are employee engagement problems at PT. MNC Networks in millennial generation. 3 Factors causing a high enough presentation of the results of pre-research conducted by researchers, the results obtained for factors that have an influence on employee engagement are leadership factors $(93 \%)$, internal communication $(100 \%)$ and company conditions/ organizational climate $(100 \%)$. The role of the leader or supervisor in leading the employees who become his sub-ordinate turns out to influence the engagement in working. According to Putra [9] leadership is the ability to influence a group towards achieving a vision or set goals. Evans says in path-goal theory that the task of the leader is to help followers achieve their goals and provide the direction or support needed to ensure the goals of the individual are consistent with the goals of the group or the organization as a whole. This path-goal theory identifies four behaviors of leadership that can be used in different situations to motivate individuals, namely: 1) Directive (directive leader), which is a leader who directly tells his followers what is expected of them, schedules work that must be done, and specifically provide guidance on how to complete the task. 2) Supportive (supportive leader), the leader who is friendly and shows concern for followers. 3) Participatory (participative leader), leaders who consult with followers and use their suggestions before making a decision. 4) Achievement orientation (achievement-oriented leader), namely leaders who are achievement oriented, who set challenging goals and expect followers to perform at their highest level [10].

Another thing taken by researchers in conducting this employee engagement research is internal communication. According to [3], that internal communication is a process of exchanging information both formally and informally between management and employees in an organization. This dimension of internal communication has also been taken from the statement of Robbins and Judge [11] namely, 1). Downward Communication; 2). Upward Communication; 3). Lateral Communication. [6], defines in Redding's research that this communication climate is a quality of individual experience from the organization's internal environment that embraces employee perceptions about messages and events related to messages that occur in the communication climate. They made the survey based on five factors which include: 1) Superiors-subordinate communication: reflects positive statements of communication between subordinates and their superiors because it includes the exchange of encouragement, understanding, and justice between these two individuals. 2) Quality of information: intended as employee satisfaction with the information and explanations they receive from management, directness throughout the organization and the integrity of the message obtained. 3) Openness / openness superior: this communication illustrates how subordinates feel about their managers in the field of providing information. Nothing is covered up and open in sharing information. 4) Opportunities for communication to the top: Reflect employees' feelings about their views and opinions that are heard and integrated into their daily work. 5) Reliability of information: Describes the accuracy of information received from management and their coworkers.

Another factor is that organizational climate also plays a role in employee engagement. Isaksen et al. [12], [13] said that organizational climate is generally related to the working atmosphere which includes the methods and methods employed by organizational members for organizational functions. Isaksen et al. [13] also stated that organizational climate has been defined as a shared perception of employees about organizational functions and practices. A positive organizational climate, good working relationships with coworkers, leaders and mutual cooperation with coworkers, can improve the effectiveness of his work, so as to make work quickly completed and able to achieve the work targets set by the company, and the existence of employee engagement both between employees and their jobs 
and the company. According to Ghanbari, Siroos Eskandari, Asghar [14], defining that organizational climate is a set of proportions in a work environment that can be measured, perceived directly or indirectly by people who live and work in that environment and are assumed to influence their motivation and behavior. 1) Structure (structure): employees perceive themselves knowing, the size, regulations, procedures, existing and certain bureaucracies in the organization. 2) Responsibility: employees perceive themselves to be a leader in doing their own work, without needing to review the decisions they make. 3) Awards (reward): employees perceive an award received is the result of a job well done. 4) Risk: employees see work risks can occur in the organization. 5) Warmth: employees see the whole friendship that is formed from the interaction of social groups in information in the organization. 6) Support: employees see the assistance provided based on the reciprocal relationship between superiors and subordinates. 7) Standards: employees see performance standards that are stated implicitly and explicitly in the organization. 8) Conflict: employees see a conflict as a result of differences in opinion from each member. 9) Identity: employees see themselves as belonging to the company and become members of a work team [15].

Joseph B. Holloway [16] Research resulted in a positive and significant correlation between the relationship between leadership behavior and organizational climate. Factors of Leadership, Internal Communication and Organizational Climate that can create Employee Engagement, According to Sapna Popli, Irfan A. Rizvi [7], employee engagement is defined as a positive, satisfying, and work-related state of mind characterized by: 1) Enthusiasm (vigor): energy and mental endurance at work, willingness to invest efforts in one's work and persistence even in the face of adversity. 2) Dedication (dedication): the presence of significant feelings, enthusiasm, inspiration, pride, and challenges. 3) Absorption: i.e. doing concentrated work attentively and working hard, where time passes quickly and a person has difficulty escaping from his job.

The background of the problem is the basis for further research to find out whether the employee engagement factor at millennial generation at PT. MNC Networks are influenced by factors of leadership, internal communication, and organizational climate.

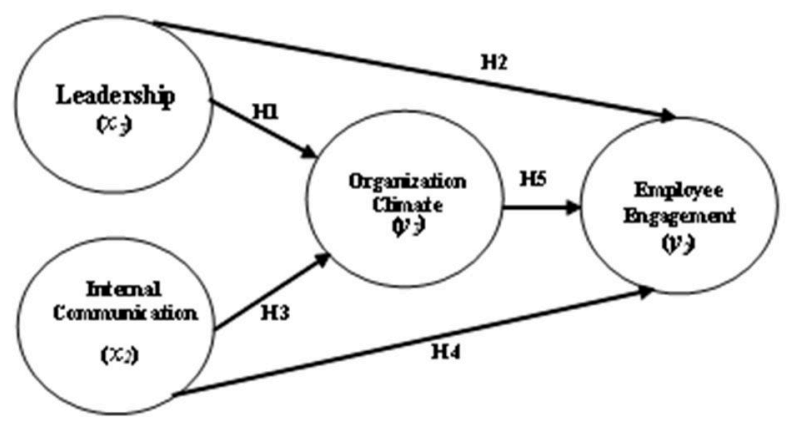

Fig 2. Research paradigm

So, the authors propose the following hypothesis:

H1: Leadership (X1) influences Organizational Climate (Y1) on millennial generation employees

H2: Leadership (X2) affect Employee Engagement (Y2) to millennial generation employees H3: Internal Communication (X2) affects Organizational Climate (Y1) on millennial generation employees 
H4: Internal Communication (X2) affects Employee Engagement (Y2) to millennial generation employees

H5: Organizational Climate (Y1) affects Employee Engagement (Y1) to millennial generation employees

Regarding the problem that the author will examine, namely employee attachment to the millennial generation in terms of leadership, communication and organizational climate aspects, there have been several previous or previous studies that can be used as a reference or reference for the author. The research was taken from 19 international journals with the following descriptions:

Table 1. Previous research

\begin{tabular}{|c|c|c|c|c|c|}
\hline No & Journal Title & Researcher & Year & Publisher & Research Conclusion \\
\hline 1. & $\begin{array}{l}\text { Engagement and } \\
\text { Retention of } \\
\text { Millenial } \\
\text { Generation in } \\
\text { Workplace, } \\
\text { through Intenal } \\
\text { Branding [17]. }\end{array}$ & Gaye Özçelik & 2015 & $\begin{array}{l}\text { International } \\
\text { Journal of } \\
\text { Business and } \\
\text { Management; Vol. } \\
\text { 10, } \\
\text { No. 3; 2015 }\end{array}$ & $\begin{array}{l}\text { This study found that the HR } \\
\text { function can be modified to } \\
\text { increase employee engagement } \\
\text { and become effective internal } \\
\text { branding for millennial } \\
\text { employees. }\end{array}$ \\
\hline 2. & $\begin{array}{l}\text { Understanding } \\
\text { the Millennial } \\
\text { Generation[18] }\end{array}$ & $\begin{array}{l}\text { Sharon A. } \\
\text { DeVaney, PhD }\end{array}$ & 2015 & $\begin{array}{l}\text { Journal of } \\
\text { Financial Service } \\
\text { Professionals, } \\
69(6), \text { pp 11-14 }\end{array}$ & $\begin{array}{l}\text { The qualitative study conducted } \\
\text { found the need for } \\
\text { entrepreneurs and managers to } \\
\text { provide meaningful work and } \\
\text { allow millennials to provide } \\
\text { input, and help millennials to } \\
\text { feel } \\
\text { compatible with a good team. }\end{array}$ \\
\hline 3. & $\begin{array}{l}\text { New } \\
\text { Generation, } \\
\text { Great } \\
\text { Expectations : } \\
\text { A Field Study } \\
\text { of Millenial } \\
\text { Generation } \\
\text { [19]. }\end{array}$ & $\begin{array}{l}\text { Eddy S.W, Ng. } \\
\text { Linda } \\
\text { Schweitzer, } \\
\text { Sean T. Lyons }\end{array}$ & 2010 & $\begin{array}{l}\text { J Bus Psychol } \\
(2010) 25: 281- \\
292\end{array}$ & $\begin{array}{l}\text { Research has found that } \\
\text { millennials are the generation } \\
\text { who want career advancement, } \\
\text { harbor prospects for quick } \\
\text { promotions and large salary } \\
\text { increases, but they have } \\
\text { realistic expectations when they } \\
\text { first start working. They want a } \\
\text { work environment that has } \\
\text { good people and looks after } \\
\text { them. }\end{array}$ \\
\hline 4. & $\begin{array}{l}\text { Factors } \\
\text { Influencing the } \\
\text { Employee } \\
\text { Engagement of } \\
\text { the Generation Y } \\
\text { Employees [20]. }\end{array}$ & $\begin{array}{l}\text { Liyanage H.M, } \\
\text { Prasadini } \\
\text { Gamage }\end{array}$ & 2017 & $\begin{array}{l}\text { Proceedings of } \\
\text { APIIT Business \& } \\
\text { Technology } \\
\text { Conference, pp. } \\
66-77\end{array}$ & $\begin{array}{l}\text { The research results found that } \\
\text { the behavior of supervisors, } \\
\text { career growth and intellectually } \\
\text { challenging work content with } \\
\text { adequate job variations and } \\
\text { work balance are factors that } \\
\text { will influence employee } \\
\text { engagement, where employee } \\
\text { engagement will address Y } \\
\text { generation's high employee } \\
\text { turnover. }\end{array}$ \\
\hline 5. & $\begin{array}{l}\text { Managing } \\
\text { Millennial } \\
\text { Communication } \\
\text { Profesionals : } \\
\text { Conectiong }\end{array}$ & $\begin{array}{l}\text { Juan Meng, } \\
\text { Ph.D., Bryan H. } \\
\text { Reber, Ph.D. }\end{array}$ & 2017 & $\begin{array}{l}\text { Journal of Turiba } \\
\text { University, } 2017\end{array}$ & $\begin{array}{l}\text { This qualitative study found } \\
\text { that the millennial generation is } \\
\text { a unique and influential } \\
\text { generation that has rapidly } \\
\text { changed the nature of }\end{array}$ \\
\hline
\end{tabular}


Generation

Attributes,

Leadership

Development,

and Employee

Engagement

[21].

6.

\begin{tabular}{|c|c|}
\hline $\begin{array}{l}\text { Leadership and } \\
\text { Emplovee }\end{array}$ & Marie Carasco- \\
\hline Engagement & Kim, and \\
\hline Proposing & Teasung Kim \\
\hline Research & \\
\hline Agendas & \\
\hline Through a & \\
\hline Review of & \\
\hline Literature [22]. & \\
\hline The Key to & Dr. Jai Prakash \\
\hline Improvement & Tripath, Mr. \\
\hline Performance : & Sunil Sharma \\
\hline Employee & \\
\hline Engagement & \\
\hline
\end{tabular}

8. Drivers of

Employee

Engagement The

Role of

Leadership Style

[7].

Sapna Popli,

Irfan A. Rizvi

ISSN: 2278-487X,

$\begin{array}{cll}\text { Nada Al Mehrzi } & 2016 & \text { International } \\ \text { and Sanjay } & & \text { Journal of } \\ \text { Kumar Singh } & \text { Productivity and } \\ & \text { Performance } \\ & \text { Management, Vol. } \\ & 65 \text { Iss 6 pp. 831 - } \\ & 843\end{array}$

Justin Walden,

Eun Hwa Jung

\& Catherine

Y.K.
2016

2015

Human Resource

Development

Review 2015

Vol. 14(1) 38-63

(C) The Author(s)

2014 Reprints and

permissions:

sagepub.com/jour

nalsPermissions.n

av

2016 IOSR Journal of

Business and

Management

(IOSR-JBM) e-

p-ISSN: 2319-

7668. Volume 18

Issue 10. Ver. IV

(October. 2016),

PP 19-25

Global Business

Review 17(4) 1-

15 (C) 2016 IMI

SAGE

Publications

sagepub.in/home.

nav

communication as consumers and communicators. By applying a unique communication style, the recruitment strategy and engagement approach will increase the relationship between millennials and their leaders and supervisors.

This study found a relationship between leadership and employee engagement through the lens of how leadership has an influence on employee engagement.

The results of this study indicate that employee involvement will influence critical business results, where the key to increasing company performance is maintaining employee engagement, efficiency, profitability, loyal clients, and company security.

The results of this study suggest that employee engagement is an important variable that will affect the organization. Apart from the leadership style that encourages employee engagement, there are other things that drive it, such as a supportive organizational culture, feedback, trust, career advancement opportunities, effective and transparent HR practices.

The results of the study resulted in a relationship between leadership, team work, perceptions of organizational support (POS), and organizational culture mediated by employee motivation.

2017 Journal of Public

Relations

Research (2017)

This research shows that certain aspects of communication in the workplace will encourage employee engagement, work involvement and commitment with millennial generations. 


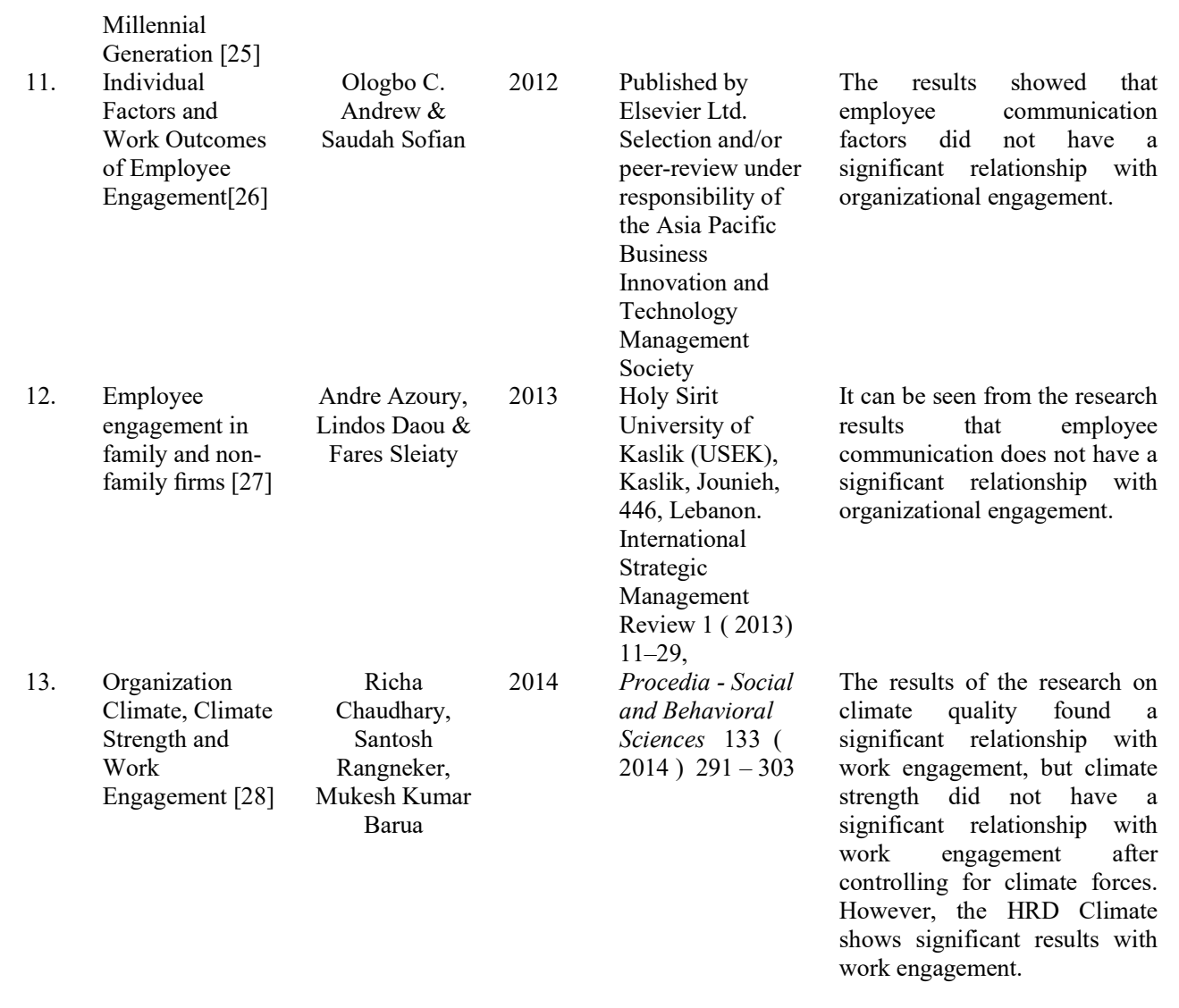

\section{Research Method}

Subject The research is employees of the millennial generation group at PT. MNC Networks with a total of 90 people. The study uses a saturated sampling technique, which is a sampling technique where all members of the population are taken as samples. Data was collected using a Likert scale, consisting of 5 answer choices namely strongly disagree (STS), disagree (TS), quite agree (CS), agree (S) and strongly agree (SS). The indicators of leadership variables that I use are based on the description of Evans [10], namely Path-Goal Theory, namely directive leaders, supportive leaders, participative leaders, and leadershiporiented achievement (achievement-oriented leaders).

Leadership variables consist of 12 items, while internal communication variables are measured using The Dennis' Communication Climate Survey [29], namely superior-sub ordinate communication, quality of information, openness / superior openness, an opportunity for upward communication consisting of 10 items. Organizational Climate Variables the author uses the theoretical foundation of Litwin, G. H., \& Stringer, R. A [30] the dimensions of the theory are Passion (vigor), Dedication (dedication), Absorption (absorption), which consists of 17 items. 
Analysis of the results of research conducted by the author is to use the Smart PLS 3.0 software. The validity test uses a factor analysis method with the output of Smart PLS in the form of AVE (Average Variance Extracted), namely with Convergent Validity and Discriminant Validity. Reliability testing uses Cronbach Alpha and Composite Reliability. This PLS also will test formative and reflective models with measurements using a Likert scale indicator, namely by designing an Inner model (describing the relationship of several variables based on substantive theory) and, Outer model (a measurement model that defines that each indicator block is related to its latent variable). Measurement of hypothesis testing is done by bootstrap resampling method.

\section{Results and Discussion}

\subsection{Convergent Validity Test}

The results of data processing carried out obtained loading factors and $t$ statistics results are for leadership variables (X1), known 2 items are invalid, and 10 items are valid, internal communication variables (X2), known 5 items are invalid and 5 items are valid, climate variables organization (Y1), known that 11 items were invalid and 7 items were valid, while the employee engagement variable (Y2), it was found 9 items were invalid and 8 items were valid.

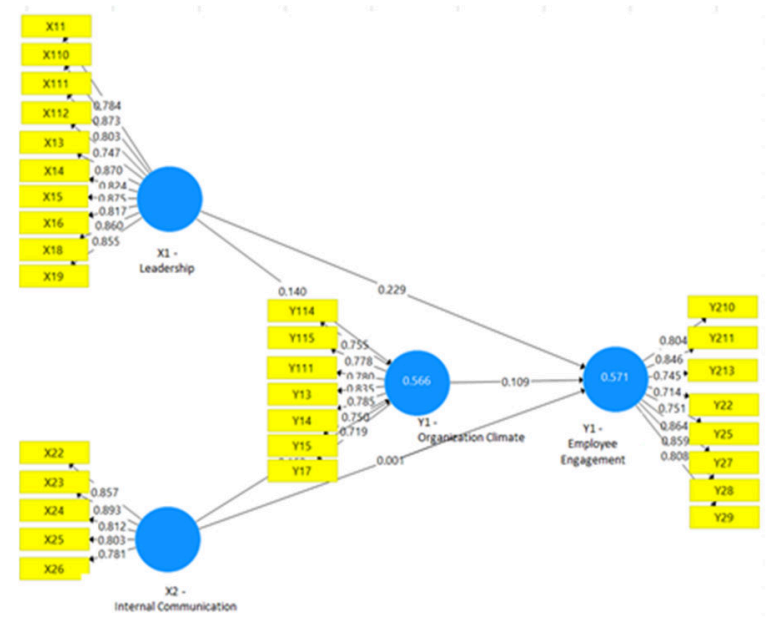

Fig 3. Model After Invalid Items are Eliminated

\subsection{Discriminant Validity Test}

The value of the cross-loading factor is used to see the measurement of Discriminant Validity, which can be obtained Directive indicators have a correlation value of 0.784 to the intended construct, namely leadership (X1), and a correlation value of 0.588 to the construct of Internal Communication (X2), 0.529 to the construct of Organizational Climate (Y1) and 0.558 on the construct of employee engagement (Y2). Indicator Communication of superiors - subordinates has a correlation value of 0.857 to the intended construct that is Internal Communication (X2), where the correlation value is higher than the correlation in the Leadership construct (X1) 0.715 , and 0.525 to the construct of Organizational Climate (Y1), and 0.540 to the construct of Employee Engagement (Y2). Indicators of responsibility have a 
correlation value to the construct that is intended, namely the Organizational Climate(Y1) amounted to 0.835 , the value is higher when compared with the correlation on the Leadership construct (X1) .610, and 0,519 to the construct of Internal Communication (X2), and 0,688 on the construct of Employee Engagement (Y2).

The Spirit Indicator has a correlation value of 0.714 to the intended construct, namely Employee Attachment(Y2), this correlation is higher than the correlation on other constructs that is equal to 0.520 to the construct of Leadership (X1), 0.468 with the construct of Internal Communication (X2), and 0,635 on the construct of Organizational Climate (Y1). All of these correlation values indicate that each indicator in the construct has a good Discriminant Validity value, because the correlation value with the intended construct is higher than the correlation value with the construct in the other block.

\subsection{Reliability Test (Composite Reliability and Cronbach Alpha).}

Reliability test is by using composite reliability and Cronbach Alpha coefficients.

Table 2. Reliability Test Results - Composite Reliability and Cronbach Alpha

\begin{tabular}{lcc}
\hline & $\begin{array}{c}\text { Composite } \\
\text { Reliability }\end{array}$ & $\begin{array}{c}\text { Cronbach's } \\
\text { Alpha }\end{array}$ \\
\hline$x_{1}-$ Kepemimpinan & 0,957 & 0,950 \\
$x_{2}-$ Komunikasi Internal & 0,917 & 0,886 \\
$y_{1}-$ Iklim Organisasi & 0,912 & 0,887 \\
$y_{2}-$ Keterikatan & 0,934 & 0,919 \\
Karyawan & & \\
\hline
\end{tabular}

\subsection{Inner Model Measurement}

Inner Model measurements are performed to see the relationship between construct value significance and R-Square research models.

Table 3. R-Square Results

\begin{tabular}{lcc}
\hline & R Square & $\begin{array}{c}\text { Adjusted R } \\
\text { Square }\end{array}$ \\
\hline$y_{1}$ - Iklim Organisasi & 0,566 & 0,556 \\
$y_{2}$ - Keterikatan Karyawan & 0,571 & 0,556 \\
\hline
\end{tabular}

Score R-Square variable intervening Organizational Climate $\left(\mathrm{Y}_{1}\right)$ is 0.566 meaning $56 \%$ of the variability of the Leadership exogenous variables $\left(\mathrm{X}_{1}\right)$ and exogenous variables Internal Communication $\left(\mathrm{X}_{2}\right)$ can be explained in the Organizational Climate intervening variable $\left(\mathrm{Y}_{1}\right)$, and the rest is explained by other variables outside the model studied. RSquare endogenous variable Employee Engagement $\left(\mathrm{Y}_{2}\right)$ is 0.571 meaning $57 \%$ of the variability of the Leadership exogenous variables $\left(\mathrm{X}_{1}\right)$ and exogenous variables Internal Communication $\left(\mathrm{X}_{2}\right)$ can be explained in endogenous variables Employee Engagement $\left(\mathrm{Y}_{2}\right)$, and the rest is explained by other variables outside the model studied. The greater the value of R-Square indicates the greater the exogenous variables can explain the endogenous variables so that the better the structural equation. The f-Square significance value is like the table below: 
Table 3. f-Square Results

\begin{tabular}{|c|c|c|c|c|}
\hline & $\begin{array}{c}x_{1} \\
\text { Kepemimpinan }\end{array}$ & $\begin{array}{c}x_{2} \\
\begin{array}{c}\text { Komunikasi } \\
\text { Internal }\end{array} \\
\end{array}$ & $\begin{array}{c}y_{1} \\
\text { Iklim } \\
\text { Organisasi }\end{array}$ & $\begin{array}{c}y_{2} \\
\text { Keterikatan } \\
\text { Karyawan } \\
\end{array}$ \\
\hline$x_{1}$-Kepemimpinan & & & 0,140 & 0,229 \\
\hline$x_{2}$ Komunikasi Internal & & & 0,163 & 0,001 \\
\hline$y_{1}$ Iklim Organisasi & & & & 0,109 \\
\hline$y_{2}$ Keterikatan Karyawan & & & & \\
\hline
\end{tabular}

Exogenous Variables in Leadership $\left(\mathrm{X}_{1}\right)$ has a "moderate" direct influence on the Organizational Climate intervening variable $\left(\mathrm{Y}_{1}\right)$ of 0.140 , and 0.229 with endogenous variables Employee Engagement $\left(\mathrm{Y}_{2}\right)$. Exogenous variables Internal Communication $\left(\mathrm{X}_{2}\right)$ has a direct effect that is "moderate" with variable Organization climate $\left(\mathrm{Y}_{1}\right)$ amounted to 0.163 , but with endogenous variables Employee Engagement $\left(\mathrm{Y}_{2}\right)$ has a "small" direct effect only 0.001. Organizational Climate Variables have a "small" direct effect with an Endogenous Employee Engagement variable that is equal to 0.109.

\subsection{Test the Significance of Influence Between Variables.}

Significance test between variables is by looking at the value of the path coefficient and T-Statistics significance value, and the results obtained:

Table 4. Effect Test Results Between Variables

\begin{tabular}{|c|c|c|c|}
\hline & $\begin{array}{c}\text { Coefficient } \\
\text { Path }\end{array}$ & $\begin{array}{c}\text { T Statistik } \\
(\mid \text { O/STDEV } \mid) \\
\end{array}$ & P Values \\
\hline$x_{1}-$ Leadership $->y_{1}-$ Organization Climate & 0,385 & 2,866 & 0,005 \\
\hline$x_{1}-$ Leadership $->y_{2}-$ Employee Engagement & 0,522 & 4,866 & 0,000 \\
\hline $\begin{array}{l}x_{2}-\text { Internal Communication }->y_{1}-\text { Organization } \\
\text { Climate }\end{array}$ & 0,415 & 3,069 & 0,002 \\
\hline $\begin{array}{l}x_{2}-\text { Internal Communication }->y_{2}-\text { Employee } \\
\text { Engagement }\end{array}$ & $-0,041$ & 0,370 & 0,712 \\
\hline $\begin{array}{l}y_{1}-\text { Organization Climate }->y_{2}-\text { Employee } \\
\text { Engagement }\end{array}$ & 0,328 & 2,739 & 0,007 \\
\hline
\end{tabular}

Table 5. Test Results for Indirect Effects Between Variables

\begin{tabular}{|c|c|c|c|}
\hline & $\begin{array}{c}\text { Coefficient } \\
\text { Path }\end{array}$ & $\begin{array}{c}\text { T Statistik } \\
(|\mathrm{O} / \mathrm{STDEV}|)\end{array}$ & P Values \\
\hline $\begin{array}{l}x_{1}-\text { Leadership }->y_{1}-\text { Organization Climate- } y_{2} \\
->- \text { Employee Engagement }\end{array}$ & 0,126 & 2,061 & 0,040 \\
\hline $\begin{array}{l}x_{2} \text {-Intenal Communication }->y_{1}- \\
\text { Organization Climate } y_{2}->\text {-Employee } \\
\text { Engagement }\end{array}$ & 0,136 & 1,806 & 0,072 \\
\hline
\end{tabular}

In this study there are also two structural models namely the first structural model is: Organizational Climate $=0.385 *$ Leadership $+0.415 *$ Internal Communication, while the second structural model is: Employee Engagement $=0.522 *$ Leadership $-0.041 *$ Internal Communication $+0.328 *$ Organizational Climate. 


\subsection{Hypothesis}

Based on the data description above, the hypothesis can be taken as follows:

a. Leadership has a direct influence on the Organizational Climate. This can be seen from the output obtained, the value of $t$-coun $\mathrm{t}>\mathrm{t}$-table $(2.866>1.657)$ or $\mathrm{P}$ values $<0.05(0.005$ $<0.05$ ), so that the hypothesis is accepted.

b. Leadership directly affects Employee Attachment. This can be seen from the output obtained, the value of $\mathrm{t}_{\text {-count }}>\mathrm{t}$-table $(4.866>1.657)$ or $\mathrm{P}$ values $<0.05(0.000<0.05)$, so that the hypothesis is accepted.

c. Internal communication has a direct effect on Organizational Climate. This can be seen from the output obtained, the value of $\mathrm{t}_{\text {-count }}>\mathrm{t}$-table $(3.069>1.657)$ or $\mathrm{P}$ values $<0.05$ $(0.002<0.05)$, so that the hypothesis is accepted.

d. Internal communication does not directly affect Employee Engagement. This can be seen from the output obtained, the $\mathrm{t}_{\text {-count }}<\mathrm{t}$-table $(0.370<1.657)$ or $\mathrm{P}$ values $>0.05(0.712>$ $0.05)$, so the hypothesis is rejected.

e. Organizational climate has an influence on Employee Engagement that is equal to t-count $>$ $\mathrm{t}$-table $(2,739>1,657)$ or $\mathrm{P}$ values $<0.05(0.007<0.05)$, so the Hypothesis is accepted.

Results that is, leadership has an influence on organizational climate, with a t-count of 2.866 or $\mathrm{P}$ values 0.005 . It shows a significant positive influence between Leadership with Organizational Climate, meaning that Leadership behavior has an influence on Organizational Climate. Leadership also has an influence on Employee Attachment, with a tcount of 4.866 or $\mathrm{P}$ values 0.005 . Leadership also has an indirect effect on Employee Attachment, seen from the t-count of 2.061 or $\mathrm{P}$ values 0.040 , showing a positive and significant direct effect between Leadership and Employee Engagement.

Internal communication has a lang effectsung against the Organizational Climate, with a t-count of 3.069 or P values 0.002. However, Internal Communication does not have a direct influence on Employee Attachment with a t-count of 0.370 or P values of 0.712 , and for an indirect relationship between Internal Communication with an Employee Engagement also does not have a relationship, seen from the t-count of 1,806 and the value of P values 0.072 . Organizational climate also has a direct influence on employee engagement, which is the tcount value of 2.739 or $P$ values 0.007 .

\section{Conclusion}

The conclusion from the data above shows that in the company the factor of forming Employee Engagement is very much dominated by the Leadership factor, namely Participatory Leadership, whereas for Internal Communication factors within the company can only form the Organizational Climate, and are unable to be part of forming the Employee Engagement towards the company, this shows that the internal communication company is very weak to be able to exert influence on employees to be more attached to the company, however the most dominant Organizational Climate, namely responsibility, is able to have a positive influence on the Employee Attachment. 


\section{References}

[1] A. A. Shahroom and N. Hussin, "Industrial Revolution 4.0 and Education," Int. J. Acad. Res. Bus. Soc. Sci., 2018, doi: 10.6007/ijarbss/v8-i9/4593.

[2] D. Lase, "Education and Industrial Revolution 4.0," Handayani J. PGSD FIP Unimed, 2019, doi: 10.24114 /jh.v10i1.14138.

[3] B. R. Kupperschmidt, "Multigeneration employees: strategies for effective management.," Health Care Manag. (Frederick)., 2000, doi: 10.1097/00126450-200019010-00011.

[4] Yanuar Surya Putra, "THEORITICAL REVIEW : TEORI PERBEDAAN GENERASI," J. Ilm. Among Makarti, 2016.

[5] K. Breevaart, A. Bakker, J. Hetland, E. Demerouti, O. K. Olsen, and R. Espevik, "Daily transactional and transformational leadership and daily employee engagement," J. Occup. Organ. Psychol., 2014, doi: 10.1111/joop.12041.

[6] W. H. Macey, B. Schneider, K. M. Barbera, and S. A. Young, Employee Engagement: Tools for Analysis, Practice, and Competitive Advantage. 2009.

[7] S. Popli and I. A. Rizvi, "Drivers of employee engagement: The role of leadership style," Glob. Bus. Rev., 2016, doi: 10.1177/0972150916645701.

[8] M. A. Memon, R. Salleh, and M. N. R. Baharom, "Linking person-job fit, person-organization fit, employee engagement and turnover intention: A three-step conceptual model," Asian Soc. Sci., 2015, doi: 10.5539/ass.v11n2p313.

[9] L. Sukariasih, I. G. P. E. Saputra, F. A. Ikhsan, A. E. Sejati, and K. Nisa, "IMPROVING THE LEARNING OUTCOMES OF KNOWLEDGE AND INQUIRY SKILL DOMAIN ON THIRD GRADE STUDENTS OF SMP NEGERI 14 KENDARI THROUGH THE GUIDED INQUIRY LEARNING MODEL ASSISTED BY SCIENCE KIT,” Geosfera Indones., 2019, doi: $10.19184 /$ geosi.v4i2.10097.

[10] M. G. Evans, "The effects of supervisory behavior on the path-goal relationship," Organ. Behav. Hum. Perform., 1970, doi: 10.1016/0030-5073(70)90021-8.

[11] S. P. Robbins and T. A. Judge, Organizational Behavior 15th Edition. 2013.

[12] A. Isaksen, "Building R egional Innovation Systems: Is Endogenous Industrial Development Possible in the Global Economy? Globalisation: A Challenge for Local Industrial Policy Regionalisation as an Aspect of Economic Globalisation,” Can. J. Reg. Sci., 2001.

[13] M. Cruice, M. Blom Johansson, J. Isaksen, and S. Horton, "Reporting interventions in communication partner training: a critical review and narrative synthesis of the literature," Aphasiology. 2018, doi: 10.1080/02687038.2018.1482406.

[14] S. Ghanbari and A. Eskandari, "Organizational Climate, Job Motivation and Organizational Citizenship Behavior,” Int. J. Manag. Perspect., 2013.

[15] L. Seibokaite and A. Endriulaitiene, "The role of personality traits, work motivation and organizational safety climate in risky occupational performance of professional drivers," Balt. J. Manag., 2012, doi: 10.1108/17465261211195892.

[16] J. B. Holloway, "Leadership Behavior and Organizational Climate: An Empirical Study in a Non-profit Organization.pdf," Emerg. Leadersh. Journeys, 2012.

[17] G. Ozcelik, "Engagement and Retention of the Millennial Generation in the Workplace through Internal Branding," Int. J. Bus. Manag., 2015, doi: 10.5539/ijbm.v10n3p99.

[18] S. A. Devaney, "Understanding the Millennial Generation,” J. Financ. Serv. Prof., 2015.

[19] E. S. W. Ng, L. Schweitzer, and S. T. Lyons, "New generation, great expectations: A field study of the millennial generation,” J. Bus. Psychol., 2010, doi: 10.1007/s10869-010-9159-4.

[20] H. M. Liyanage and P. Gamage, "Factors influencing the Employee Engagement of the Generation Y Employees," Proc. APIIT Bus. Technol. Conf., 2017.

[21] J. P. Meng, B. H. P. Reber, and H. P. Rogers, "Managing Millennial Communication Professionals: Connecting Generation Attributes, Leadership Development, and Employee Engagement," 2017.

[22] M. Carasco-Saul, W. Kim, and T. Kim, "Leadership and Employee Engagement: Proposing Research Agendas Through a Review of Literature," Human Resource Development Review. 2015, doi: 10.1177/1534484314560406. 
[23] D. J. P. Tripathi and M. S. Sharma, "The Key to Improve Performance:Employee Engagement,” IOSR J. Bus. Manag., 2016, doi: 10.9790/487x-1810041925.

[24] N. Al Mehrzi and S. K. Singh, "Competing through employee engagement: a proposed framework,” Int. J. Product. Perform. Manag., 2016, doi: 10.1108/IJPPM-02-2016-0037.

[25] J. Walden, E. H. Jung, and C. Y. K. Westerman, "Employee communication, job engagement, and organizational commitment: A study of members of the Millennial Generation," J. Public Relations Res., 2017, doi: 10.1080/1062726X.2017.1329737.

[26] O. C. Andrew and S. Sofian, "Individual Factors and Work Outcomes of Employee Engagement," Procedia - Soc. Behav. Sci., 2012, doi: 10.1016/j.sbspro.2012.03.222.

[27] A. Azoury, L. Daou, and F. Sleiaty, "Employee engagement in family and non-family firms," Int. Strateg. Manag. Rev., 2013, doi: 10.1016/j.ism.2013.08.002.

[28] R. Chaudhary, S. Rangnekar, and M. K. Barua, "Organizational Climate, Climate Strength and Work Engagement," Procedia - Soc. Behav. Sci., 2014, doi: 10.1016/j.sbspro.2014.04.195.

[29] S. M. Nordin, S. Sivapalan, E. Bhattacharyya, H. H. W. F. W. Ahmad, and A. Abdullah, "Organizational Communication Climate and Conflict Management: Communications Management in an Oil and Gas Company," Procedia - Soc. Behav. Sci., 2014, doi: 10.1016/j.sbspro.2013.12.587

[30] K. Umar, "Employee engagement organizational performance," adademia.edu, 2014. 